\title{
PENGARUH PENDAPATAN ASLI DAERAH, DANA ALOKASI UMUM, DAN DANA ALOKASI KHUSUS TERHADAP PENGALOKASIAN ANGGARAN BELANJA MODAL (Studi Empiris pada Pemerintahan Daerah Kabupaten/Kota Provinsi Banten)
}

\author{
Oleh : \\ Heriston Sianturi \\ dan \\ Anastasya Astrid Eka Putri
}

\begin{abstract}
The purpose of this research is to know the analyze whether Regional Own Revenue, General Allocation Fund, and Special Allocation Fund to the Allocation of Capital Expenditure Budget in regency/city in Banten province. This research also aims to find out how big Contribution of Original Income, General Allocation Fund, and Special Allocation Fund to Allocation of Capital Expenditure Budget in Banten Province. The data used in this research is secondary data from 2012 - 2016 obtained from DJPK website (Directorate General of Fiscal Balance). The analytical method that used is multiple linear regression analysis.

Based on the regression outcome, theconclusion has already known that Regional Own Revenue, General Allocation Fund, and Special Allocation Fund have positive and significant influences to Capital Expenditure Budget. The determination coefficient value for $Y$ is 0,887, it means 88,7\% of Capital Expenditure Budget can be explained by three independent variables: Regional Own Revenue, General Allocation Fund, and Special Allocation Fund. Meanwhile, the rest of 11,3\% $(100 \%-88,7 \%)$ can be explained by another factor.
\end{abstract}

Keywords: Regional Own Revenue, General Allocation Fund, Special Allocation Fund, and Capital Expenditure Budget 


\begin{abstract}
ABSTRAK
Penelitian bertujuan untuk mengetahui Pengaruh Pendapatan Asli Daerah, Dana Alokasi Umum, dan Dana Alokasi Khusus terhadap Pengalokasian Anggaran Belanja Modal pada Kabupaten/Kota di Provinsi Banten. Penelitian ini juga bertujuan untuk mengetahui seberapa besar Kontribusi Pendapatan Asli Daerah, Dana Alokasi Umum, dan Dana Alokasi Khusus terhadap Pengalokasian Anggaran Belanja Modal di Provinsi Banten, dengan jenis data sekunder berupa Anggaran Pendapatan dan Belanja Daerah (APBD) Kabupaten/Kota DJPK (Direktorat Jendral Perimbangan Keuangan) Provinsi Banten periode tahun 2012-2016, Metode analisis yang digunakan adalah dengan analisis regresi linier berganda.

Berdasarkan hasil Uji Regresi, maka diketahui Pengaruh Pendapatan Asli Daerah, Dana Alokasi Umum, dan Dana Alokasi Khusus mempunyai pengaruh yang positif dan signifikan terhadap Anggaran Belanja Modal. Nilai koefisien determinasi $\left(\mathrm{R}^{2}\right)$ untuk $\mathrm{Y}$ sebesar 0,887, hal ini berarti 88,7\% variabel Anggaran Belanja Modal dapat dijelaskan oleh ketiga variabel bebas Pengaruh Pendapatan Asli Daerah, Dana Alokasi Umum, dan Dana Alokasi Khusus. Sedangkan sisanya 11,3\% $(100 \%-88,7 \%)$ dijelaskan oleh sebab - sebab lain yang tidak dimasukan dalam model.
\end{abstract}

Kata Kunci : Pendapatan Asli Daerah, Dana Alokasi Umum, Dana Alokasi Khusus, dan Anggaran Belanja Modal 


\section{PENDAHULUAN}

Pemerintahan Daerah yang berada di wilayah Republik Indonesia tidak dapat terlepas dari adanya peran dari pemerintah pusat dalam hal menjalankan fungsi pemerintahan. Namun, dengan adanya Undang-Undang Nomor 23 Tahun 2014 Tentang Pemerintahan Daerah, yang berlaku pada setiap daerah di wilayah Republik Indonesia menjadikan pemerintah daerah memiliki pelimpahan kewenangan dengan cakupan luas untuk mengurus rumah tangganya sendiri serta meminimalisir campur tangan pemerintah pusat.

Dengan cakupan tersebut, pemerintah daerah dapat mempermudah dalam mengatur segala kas milik daerah untuk dipergunakan dalam public service di daerah. Peraturan Pemerintah (PP) Nomor 71 Tahun 2010 memberikan penegasan bahwa daerah memiliki kewenangan untuk menentukan alokasi sumber dana ke dalam Belanja Modal dengan menganut asas kepatutan, kebutuhan dan kemampuan daerah. Pemerintah daerah, bekerjasama dengan Dewan Perwakilan Rakyat Daerah sebagai lembaga legislatif terlebih dahulu menentukan Kebijakan Umum APBD (KUA) dan Prioritas \& Plafon Anggaran Sementara (PPAS) sebagai petunjuk (guidance) dalam pengalokasian sumber dana dalam APBD. KUA dan PPAS merupakan konkretisasi dari hasil penjaringan aspirasi masyarakat sehingga diperoleh gambaran yang cukup tentang kebijakan jangka pendek, jangka menengah, dan kebijakan jangka panjang yang berkaitan dengan kebijakan pengelolaan keuangan daerah.

Belanja Modal digunakan untuk pengeluaran yang dilakukan dalam rangka pembelian/pengadaan atau pembangunan aset tetap berwujud yang mempunyai nilai manfaat lebih dari dua belas bulan untuk digunakan dalam kegiatan pemerintahan (Nordiawan, 2012). Belanja Modal sangat berkaitan dengan perencanaan keuangan jangka panjang, terutama pembiayaan untuk pemeliharaan aset tetap yang dihasilkan dari Belanja Modal tersebut. Pemerintah daerah mengalokasikan dana dalam bentuk anggaran Belanja Modal dalam APBD untuk menambah aset tetap dan aset lainnya yang memberi manfaat lebih dari satu periode akuntansi.

Anggaran Belanja Modal ini didasarkan pada kebutuhan daerah akan sarana dan prasarana, baik untuk kelancaran pelaksanaan tugas pemerintah maupun untuk fasilitas publik. Pada dasarnya, pemerintah tidak mempunyai uang yang dimiliki sendiri, sebab seluruhnya adalah milik publik (Mardiasmo, 2002), oleh karena itu dalam upaya meningkatkan kualitas pelayanan publik, pemerintah daerah seharusnya mengubah komposisi belanjanya. Selama ini belanja daerah lebih banyak digunakan untuk belanja rutin yang relatif kurang produktif. Juli Panglima Sarangih (2003) menyatakan bahwa pemanfaatan belanja hendaknya dialokasikan untuk hal-hal produktif misalnya untuk melakukan aktivitas pembangunan.

Dalam Undang-undang Nomor 23 Tahun 2014 disebutkan bahwa salah satu sumber pendapatan daerah adalah Pendapatan Asli Daerah (PAD), yang terdiri dari hasil pajak daerah, hasil retribusi daerah, hasil pengelolaan kekayaan daerah yang dipisahkan, dan lain-lain PAD yang sah.

Menurut Mardiasmo (2002) saat ini masih banyak masalah yang dihadapi pemerintah daerah terkait dengan upaya meningkatkan penerimaan daerah keterbatasan sarana dan prasarana yang tidak mendukung untuk investasi menimbulkan pertanyaan bagaimana sebenarnya PAD terhadap Belanja Modal, apakah karena PAD yang rendah atau alokasi yang kurang tepat. Setiap daerah berbekal kemampuan keuangan yang beragam dalam mendanai kegiatan-kegiatannya, hal ini menimbulkan ketimpangan fiskal antara satu daerah dengan daerah lainnya, oleh karena itu untuk mengatasi ketimpangan fiskal pemerintah pusat mengalokasikan dana yang bersumber kepada APBN untuk mendanai kebutuhan daerah dalam pelaksanaan desentralisasi.

Salah satu dana perimbangan dari pemerintah ini adalah Dana Alokasi Umum (DAU) yang pengalokasiannya menekankan aspek pemerataan dan keteradilan yang selaras dengan penyelengaraan urusan pemerintahan (Undang-Undang Nomor 23 Tahun 2014). Dengan adanya transfer dari pusat ini diharapkan pemerintah daerah mampu mengalokasikan PAD yang didapatnya 
untuk membiayai Belanja Modal di daerahnya. Namun pada kenyataannya, transfer dari pemerintah pusat merupakan sumber dana utama pemerintah daerah untuk membiayai operasi utamanya seharihari atau belanja daerah. Belanja Modal merupakan bagian dari belanja daerah yang juga didanai dari DAU, dan diperhitungkan oleh pemerintah daerah dalam APBD.

Dana transfer dari pemerintah pusat ke pemerintah daerah selain DAU adalah Dana Alokasi Khusus (DAK) yaitu dana yang bersumber dari pendapatan APBN yang dialokasikan kepada daerah tertentu dengan tujuan untuk membantu mendanai kegiatan khusus yang merupakan urusan daerah dan sesuai dengan prioritas nasional (Undang-Undang Nomor 33 Tahun 2004).

Penggunaan DAK diatur oleh pemerintah pusat, dan hanya digunakan untuk kegiatan pendidikan, kesehatan, keluarga berencana, insfrastruktur jalan dan jembatan, insfrastruktur irigasi, insfrastruktur air minum dan sanitasi, prasarana pemerintah daerah, lingkungan hidup, kehutanan, sarana prasarana pedesaan, perdagangan, pertanian serta perikanan dan kelautan yang semuanya itu termasuk dalam Belanja Modal dan pemerintah daerah diwajibkan untuk mengalokasikan dana pendamping sebesar $10 \%$ dari nilai DAK yang diterimanya untuk kegiatan fisik.

\section{Perumusan Masalah}

Perumusan masalah penelitian ini adalah : Apakah Pendapatan Asli Daerah (PAD), Dana Alokasi Umum (DAU) dan Dana Alokasi Khusus (DAK) berpengaruh terhadap Anggaran Belanja Modal Kabupaten/Kota di Provinsi Banten?

\section{Tujuan Penelitian}

Tujuan penelitian untuk menguji pengaruh variabel Pendapatan Asli Daerah (PAD), Dana Alokasi Umum (DAU) dan Dana Alokasi Khusus (DAK) terhadap Anggaran Belanja Modal Kabupaten/Kota di Provinsi Banten.

\section{LANDASAN TEORI}

\section{Pendapatan Asli Daerah (PAD)}

Pendapatan Asli Daerah (PAD) adalah penerimaan daerah dari sektor pajak daerah, retribusi daerah, hasil perusahaan milik daerah, hasil pengelolaan kekayaan daerah yang dipisahkan, dan lainlain pendapatan asli daerah yang sah ( Mardiasmo; 2002). Selanjutnya menurut Herlina Rahman (2005) Pendapatan Asli Daerah merupakan pendapatan daerah yang bersumber dari hasil pajak daerah, hasil distribusi, hasil pengelolaan kekayaan daerah yang dipisahkan dan lain-lain. Pendapatan asli daerah yang sah dalam menggali pendanaan dalam pelaksanaan otonomi daerah sebagai perwujudan asas desentralisasi.

Pengertian pendapatan asli daerah berdasarkan Undang-Undang Nomor 33 Tahun 2004 tentang Perimbangan Keuangan Antara Pusat dan Daerah Pasal 1 angka 18 bahwa "Pendapatan asli daerah, selanjutnya disebut PAD adalah pendapatan yang diperoleh daerah yang dipungut berdasarkan peraturan daerah sesuai dengan peraturan perundang-undangan”.

PAD merupakan pendapatan daerah yang bersumber dari hasil pajak daerah, hasil retribusi Daerah, basil pengelolaan kekayaan daerah yang dipisahkan, dan lain-lain pendapatan asli daerah yang sah, bertujuan untuk memberikan keleluasaan kepada daerah dalam menggali pendanaan dalam pelaksanaan otonomi daerah sebagai mewujudan asas desentralisasi. (Penjelasan UU No.33 Tahun 2004). Selanjutnya PAD dapat merujuk pada Peraturan Menteri Dalam Negeri atau Permendagri No. 37 Tahun 2014 tentang Pedoman Penyusunan Anggaran Pendapatan dan Belanja Daerah (APBD). 
Dalam peraturan tersebut, Pendapatan Asli Daerah menjadi salah satu bagian dari Pendapatan Daerah yang dianggarkan dalam APBD Tahun Anggaran dan merupakan perkiraan yang terukur secara rasional dan memiliki kepastian serta dasar hukum penerimaannya.

\section{Dana Alokasi Umum (DAU)}

Dana Alokasi Umum (DAU) adalah dana yang bersumber dari pendapatan APBN yang dialokasikan dengan tujuan pemerataan kemampuan keuangan antardaerah untuk mendanai kebutuhan daerah dalam rangka pelaksanaan desentralisasi. DAU tersebut dialokasikan untuk provinsi dan kabupaten/kota. (Nordiawan, 2012).

Dana alokasi umum berdasarkan persentase tertentu dari pendapatan dalam negeri neto yang ditetapkan dalam APBN. Dana alokasi umum untuk suatu daerah ditetapkan berdasarkan kriteria tertentu yang menekan pada aspek pemerataan dan keadilan yang selaras dengan penyelenggaraan urusan pemerintahan. (Renyowijoyo, 2010)

Persentase Pembagian DAU antara Provinsi dan Kabupaten/Kota adalah 10\% dari total DAU Nasional dialokasikan kepada Provinsi dan 90\% dari total DAU Nasional dialokasikan kepada Kabupaten/Kota. Perhitungan besaran DAU secara nasional adalah minimal 26\% dari Pendapatan Dalam Negeri Netto (PDN Netto), dengan besaran alokasi DAU per daerah dihitung menggunakan rumus/formulasi yang tertuang dalam Undang-Undang Nomor 33 Tahun 2004 dan Peraturan Pemerintah Nomor 71 Tahun 2010.

\section{Rumusan Formula DAU adalah sebagai berikut :}

$\mathrm{DAU}=$ Alokasi Dasar $(\mathrm{AD})+$ Celah Fiskal $(\mathrm{CF})$, dimana $\mathrm{AD}=$ Proyeksi Belanja Gaji Pegawai Negeri Sipil Daerah (PNSD) dalam setahun kedepan, $\mathrm{CF}=$ Kebutuhan Fiskal $(\mathrm{KbF})$ Kapasitas Fiskal $(\mathrm{KpF}) . \mathrm{KbF}=$ Total Belanja Daerah $(\mathrm{TBD}) \times((\%$ Jumlah Penduduk $)+(\%$ Luas Wilayah $)+(\%$ Invers Indeks Pembangunan Manusia (IPM) $)+(\%$ Indeks Kemahalan Konstruksi $(\mathrm{IKK}))+(\%$ Pendapatan Domestik Regional Bruto $), \mathrm{KpF}=(\%$ Pendapatan Asli Daerah $)+(\%$ Dana Bagi Hasil)

Jumlah Dana Alokasi Umum setiap tahun ditentukan berdasarkan keputusan. Setiap Provinsi/Kabupaten/Kota berhak menerima DAU dengan besaran yang tidak sama. Daerah dimungkinkan mendapatkan DAU lebih besar atau lebih kecil atau sama dengan DAU tahun sebelumnya. Bahkan di beberapa daerah yang memiliki Kapasitas Fiskal sangat besar dimungkinkan untuk tidak mendapat DAU $(\mathrm{DAU}=0)$.

\section{Dana Alokasi Khusus (DAK)}

Dana Alokasi Khusus dialokasikan dari APBN kepada daerah tertentu dalam rangka pendanaan pelaksanaan desentralisasi untuk:

1. Mendanai kegiatan khusus yang ditentukan pemerintah atas

dasar prioritas nasional.

2. Mendanai kegiatan khusus yang diusulkan daerah tertentu (Renyowijoyo, 2010)

Dana Alokasi Khusus (DAK) merupakan dana yang bersumber dari pendapatan APBN yang dialokasikan pada daerah tertentu untuk membantu mendanai kegiatan khusus yang merupakan urusan daerah dan merupakan bagian dari program yang menjadi prioritas nasional. Daerah tertentu adalah daerah yang dapat memperoleh alokasi DAK berdasarkan kriteria umum, kriteria khusus, dan kriteria teknis. Dan, program yang menjadi prioritas nasional dimuat dalam Renja Pemerintahan tahun anggaran bersangkutan. Besaran DAK ditetapkan setiap tahun dalam APBN (Nordiawan, 2012).Peraturan Pemerintah (PP) Nomor 71 Tahun 2010 menyatakan bahwa program yang menjadi prioritas nasional dimuat dalam Rencana Kerja Pemerintah (RKP) tahun anggran bersangkutan. 
DAK merupakan dana yang bersumber dari pendapatan APBN yang dialokasikan pada daerah tertentu untuk membantu mendanai kegiatan khusus yang merupakan urusan daerah dan merupakan bagian dari program yang menjadi prioritas nasional. Daerah tertentu adalah daerah yang dapat memperoleh alokasi DAK berdasarkan kriteria umum, kriteria khusus, dan kriteria teknis. Dan, program yang menjadi prioritas nasional dimuat dalam Renja Pemerintah tahun anggaran bersangkutan.

berikut :

Besaran DAK ditetapkan setiap tahun dalam APBN dengan kriteria pengalokasian sebagai

1. Kriteria Umum, dirumuskan berdasarkan kemampuan keuangan daerah yang tercermin dari penerimaan umum APBD setelah dikurangi belanja PNSD;

2. Kriteria Khusus, dirumuskan berdasarkan peraturan perundang-undangan yang mengatur penyelenggaraan otonomi khusus dan karakteristik daerah.

3. Kriteria Teknis, yang disusun berdasarkan indikator-indikator yang dapat menggambarkan kondisi sarana dan prasarana, serta pencapaian teknis pelaksanaan kegiatan DAK di daerah.

Alokasi DAK per daerah ditetapkan dengan Peraturan Menteri Keuangan, dengan penghitungan alokasi melalui dua tahapan :

1) Penentuan daerah tertentu yang menerima DAK; dan

2) Penentuan besaran alokasi DAK masing-masing daerah, dengan penentuan daerah tertentu yang memenuhi kriteria dan perhitungan indeks berdasarkan kriteria umum, kriteria khusus, dan kriteria teknis.

\section{Anggaran Belanja Modal}

Belanja Modal merupakan belanja Pemerintah Daerah yang manfaatnya melebihi satu tahun anggaran dan akan menambah aset atau kekayaan daerah dan selanjutnya akan menambah belanja yang bersifat rutin seperti biaya pemeliharaan pada kelompok belanja administrasi umum (Halim; 2004). Belanja modal dapat juga disimpulkan sebagai pengeluaran yang dilakukan dalam rangka pembentukan modal yang sifatnya menambah aset tetap/investasi yang memberikan manfaat lebih dari satu periode akuntansi, termasuk didalamnya adalah pengeluaran untuk biaya pemeliharaan yang sifatnya mempertahankan atau menambah masa manfaat, meningkatkan kapasitas dan kualitas aset. Belanja

Modal dapat dikategorikan dalam 5 (lima) kategori utama :

1.Belanja Modal Tanah

Belanja Modal Tanah adalah pengeluaran/biaya yang digunakan untuk pengadaan/pembelian/pembebasan penyelesaian, balik nama dan sewa tanah, pengosongan, pengurungan, perataan, pematangan tanah, pembuatan sertifikat, dan pengeluaran lainnya sehubungan dengan perolehan hak atas tanah dan sampai tanah dimaksud dalam kondisi siap pakai.

2. Belanja Modal Peralatan dan Mesin

Belanja Modal Peralatan dan Mesin adalah pengeluaran/biaya yang digunakan untuk pengadaan/penambahan/penggantian, dan peningkatan kapasitas peralatan dan mesin serta inventori kantor yang memberikan manfaat lebih dari 12 (dua belas) bulan dan sampai peralatan dan mesin dimaksud dalam kondisi siap pakai.

3. Belanja Modal Gedung dan Bangunan

Belanja Modal Gedung dan Bangunan adalah pengeluaran/biaya yang digunakan untuk pengadaan/penambahan/penggantian, dan termasuk pengeluaran untuk perencanaan, pengawasan, 
dan pengelolaan pembangunan gedung dan bangunan yang menambah kapasitas sampai gedung dan bangunan dimaksud dalam kondisi siap pakai.

4. Modal Jalan, Irigasi, dan Jaringan

Belanja Modal Jalan, Irigasi, dan Jaringan adalah pengeluaran/biaya yang digunakan untuk pengadaan/ penambahan/ penggantian/ peningkatan/ pembangunan/ pembuatan serta perawatan, dan termasuk pengeluaran untuk perencanaan, pengawasan, dan pengelolaan jalan, irigasi, dan jaringan yang menambah kapasitas sampai jalan, irigasi, dan jaringan dimaksud dalam kondisi siap pakai.

\section{Belanja Modal Fisik Lainnya}

Belanja Modal Fisik Lainnya adalah pengeluaran/biaya yang digunakan untuk pengadaan/ penambahan/ penggantian/ peningkatan/ pembangunan/ pembuatan serta perawatan terhadap fisik lainnya yang tidak dapat dikategorikan kedalam kriteria belanja modal tanah, peralatan dan mesin, gedung dan bangunan, dan jalan, irigasi dan jaringan, termasuk dalam belanja ini adalah belanja modal kontrak sewa beli, pembelian barang-barang kesenian, barang purbakala dan barang untuk museum, hewan ternak dan tanaman, buku-buku, dan jurnal ilmiah.

Aset tetap merupakan prasyarat utama dalam memberikan pelayanan publik oleh pemerintah daerah. Untuk menambah aset tetap, pemerintah daerah mengalokasian dana dalam bentuk belanja modal dalam APBD. Alokasi belanja modal ini didasarkan pada kebutuhan daerah akan sarana dan prasarana, baik unutk kelancaran pelaksanaan tugas pemerintahan maupun fisik fasilitas publik.

Biasanya setiap tahun diadakan pengadaan aset tetap oleh pemerintah daerah, sesuai dengan prioritas anggaran dan pelayanan publik yang memberikan dampak jangka panjang secara finansial. Belanja Modal sebagaimana dimaksud dalam pasal 50 huruf c Pemendagri No 59 Tahun 2007 tentnag perubahan Pemendagri Nomor 13/2006 Tentang Pengelolaan Keuangan Daerah digunakan untuk pengeluaran yang dilakukan dalam rangka pengadaan aset tetap berwujud yang mempunyai nilai manfaat lebih dari 12 (dua belas) bulan untuk digunakan dalam kegiatan pemerintahan.

Pada pasal 53 ayat 2 Permendagri Nomor 59 Tahun 2007 ditentukan bahwa nilai aset tetap berwujud yang di anggarkan dalam belanja modal sebesar harga beli/bangun aset ditambah seluruh belanja yang terkait dengan pengadaan/pembangunan aset sampai aset tersebut siap digunakan. Kemudian pada pasal 53 ayat 4 Permendagri Nomor 59 Tahun 2007 disebutkan bahwa Kepala Daerah menetapkan batal minimal kapitalisasi sebagai dasar pembebanan belanja modal selain memenuhi batas minimal juga pengeluaran anggaran untuk belanja barang tersebut harus memberi manfaat lebih dari satu periode akuntansi bersifat tidak rutin.

Ketentuan hal ini sejalan dengan PP 24 tahun 2004 Tentang Standar Akuntansi Pemerintahan (PSAP) khususnya PSAP nomor 7 tentang akuntansi aset tetap.

\section{Pengaruh Pendapatan Asli Daerah dengan Anggaran Belanja Modal}

Salah satu sumber pembiayaan belanja daerah adalah Pendapatan asli daerah (PAD) digunakan, oleh sebab itu pemerintah daerah seoptimal mungkin berusaha untuk menggunakan segala potensi daerah yang dimilikinya untuk memperoleh peningkatan PAD. Hal tersebut dilakukan oleh pemerintah daerah supaya dapat membiayai dari kegiatan atas fungsi public service untuk masyarakat, oleh karena itu pemerintah daerah perlu menganggarkan belanja modal dari belanja daerah untuk menciptakan sarana dan prasarana untuk masyarakat di daerah. Dengan adanya peningkatan dari PAD diharapkan dapat berpengaruh secara signifikan terhadap belanja modal. 


\section{Pengaruh Dana Alokasi Umum dengan Anggaran Belanja Modal}

Sumber pembiayaan belanja daerah lainnya adalah berupa dana perimbangan dari pemerintah pusat, adalah Dana Alokasi Umum (DAU) yaitu adana yang berasal dari Anggaran Pendapatan Belanja Negara (APBN), lalu dialokasikan dengan tujuan untuk pemerataan keuangan tingkat daerah untuk membiayai keperluan dalam rangka pelaksanaan desentralisasi. Dengan demikian terjadi transfer yang cukup signifikan dari pemerintah pusat ke pemerintah daerah lalu menggunakan dana ini untuk fungsi layanan dasar umum. Fungsi dari DAU ini menyerupai PAD yaitu sama-sama membiayai kebutuhan belanja daerah termasuk salah satunya adalah belanja modal. Meskipun DAU merupakan dana yang bersumber dari pemerintah pusat, ternyata di daerah banyak masih bergantung pada DAU ini dalam mendanai kebutuhan belanja modal. Dengan adanya DAU ini diharapkan dapat berpengaruh terhadap belanja modal secara signifikan.

\section{Pengaruh Dana Alokasi Khusus dengan Anggaran Belanja Modal}

Pengaturan pemanfaatan dana alokasi khusus yang dialokasikan untuk mendanai kebutuhan fisik dengan tujuan dapat meningkatkan sarana dan prasarana guna mendukung laju pertumbuhan ekonomi, sesuai amanat Peraturan Menteri Keuangan seharusnya pemerintah daerah dapat meningkatkan alokasi belanja pembangunan infrastrukturnya lebih tinggi dengan pendanaan yang berasal dari dana alokasi khusus tersebut tersebut tentunya akan berimbas pada peningkatan pengalokasian belanja untuk fisik yang dalam APBD terakomodir dalam jenis belanja barang modal.

\section{Pengaruh PAD, DAU, dan DAK terhadap Anggaran Belanja Modal}

Pendapatan Asli Daerah (PAD), Dana Alokasi Umum (DAU), dan Dana Alokasi Khusus (DAK) merupakan sumber-sumber penerimaan daerah yang digunakan oleh pemerintah daerah untuk pembiayaan atas belanja daerah termasuk belanja modal yang dilakukan pada pemerintah daerah dalam rangka memberikan public service kepada masyarakat. Dengan demikian peranan PAD, DAU, dan DAK cukup penting pada pemerintah daerah saat ini.

Pemerintah daerah perlu mengatur belanja daerah dan berfokus pada belanja modal demi pembangunan daerah dalam pelaksanaan public service kepada masyarakat. Untuk itu, pemerintah daerah perlu mengoptimalkan penggunaan dari sumber penerimaan daerah termasuk didalamnya yaitu PAD, DAU, dan DAK. Bila suatu daerah terjadi dengan adanya peningkatan pada PAD, DAU, dan DAK secara bersamaan maka diharapkan dapat berpengaruh secara signifikan terhadap belanja modal.

\section{METODOLOGI PENELITIAN}

\section{Desain Penelitian}

Desain menggunakan penelitian kausal yang merupakan penelitian untuk mengetahui pengaruh antara satu atau lebih variabel bebas (independent variable) terhadap variabel terikat (dependent variable). Variabel bebas (independent variable) adalah Pendapatan Asli Daearah (PAD), Dana Aloksi Umum (DAU), dan Dana Alokasi Khusus (DAK). Sedangkan variabel terikat (dependent variable) adalah Anggaran Belanja Modal.

\section{Hipotesis Penelitian}

Hipotesis adalah pernyataan sementara atau dugaan yang paling memungkinkan yang masih harus dicari kebenarannya, dengan tujuan untu mengetahui untuk mengetahui pengaruh Pendapatan Asli Daearah (PAD), Dana Aloksi Umum (DAU), dan Dana Alokasi Khusus (DAK) terhadap Anggaran Belanja Modal. Hipotesis yang akan diuji adalah sebagai berikut : 
H01 : Tidak terdapat pengaruh Pendapatan Asli Daerah terhadap Anggaran Belanja Modal

Ha1 : Terdapat pengaruh Pendapatan Asli Daerah terhadap Anggaran Belanja Modal

H02 : Tidak terdapat pengaruh Dana Alokasi Umum terhadap Anggaran Belanja Modal

Ha2 : Terdapat pengaruh Dana Alokasi Umum terhadap Anggaran Belanja Modal

H03 : Tidak terdapat pengaruh Dana Alokasi Khusus (DAK) terhadap Anggaran Belanja Modal

Ha3 : Terdapat pengaruh Dana Alokasi Khusus (DAK) terhadap Anggaran Belanja Modal

H04 : Tidak terdapat pengaruh secara bersam-sama Pendapatan Asli Daerah (PAD), Dana Alokasi Umum (DAU), dan Dana Alokasi Khusus (DAK) terhadap Anggaran Belanja Modal

Ha4 : Terdapat pengaruh secara bersam-sama Pendapatan Asli Daerah (PAD), Dana Alokasi Umum (DAU), dan Dana Alokasi Khusus (DAK) terhadap Anggaran Belanja Modal.

\section{Populasi dan Sampel}

Populasi penelitian adalah Anggaran Pendapatan dan Belanja Daerah (APBD) Kabupaten/Kota di Provinsi Banten periode tahun 2012 - 2016 dan Pengambilan sampel dengan menggunakan sampel jenuh atau sensus.

\section{Jenis Data}

Data dalam penelitian ini adalah data sekunder berupa Anggaran Pendapatan dan Belanja Daerah (APBD) Kabupaten/Kota DJPK (Direktorat Jendral Perimbangan Keuangan) Provinsi Banten.

\section{Operasional Variabel Penelitian}

Operasional variabel penelitian diuraikan sebagai berikut :

\begin{tabular}{|c|c|c|}
\hline Variabel & Indikator & Skala \\
\hline $\begin{array}{l}\text { Pendapatan Asli } \\
\text { Daerah (X1) } \\
\text { Undang-Undang } \\
\text { Nomor } 33 \text { Tahun } \\
2004\end{array}$ & $\begin{array}{l}\text { Pendapatan Asli Daerah = Pajak Daerah + Retribusi } \\
\text { Daerah + hasil Pengelolaan Kekayaan Daerah yang } \\
\text { dipisahkan + Lain-lain Pendapatan yang sah. }\end{array}$ & Rasio \\
\hline $\begin{array}{l}\text { Dana Alokasi } \\
\text { Umum (X2) } \\
\text { Undang-Undang } \\
\text { Nomor } 33 \text { Tahun } \\
2004\end{array}$ & $\begin{array}{l}\text { DAU Kabupaten } / \text { kota }=90 \% \quad \text { x } 25 \% \text { x } \\
\text { (Pendapatan Dalam Negeri) } \times \text { Bobot DAU. }\end{array}$ & Rasio \\
\hline $\begin{array}{l}\text { Dana Alokasi } \\
\text { Khusus (X3) } \\
\text { Undang-Undang } \\
\text { Nomor 33 Tahun } \\
2004\end{array}$ & $\begin{array}{l}\text { Rumus berdasarkan kemampuan keuangan daerah } \\
\text { yang dicerminkan dari penerimaan umum APBD } \\
\text { setelah dikurangi belanja pegawai negeri sipil daerah. }\end{array}$ & Rasio \\
\hline 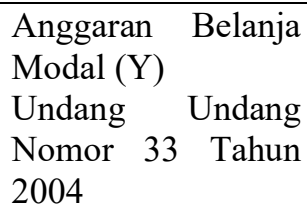 & $\begin{array}{l}\text { Anggaran Belanja Modal }=\text { Belanja tanah }+ \text { belanja } \\
\text { peralatan mesin }+ \text { belanja gedung dan bangunan }+ \\
\text { belanja jalan, irigasi, jaringan }+ \text { belanja aset lainnya. }\end{array}$ & Rasio \\
\hline
\end{tabular}




\section{HASIL DAN PEMBAHASAN}

\section{Deskripsi Data Penelitian}

Objek dari penelitian ini adalah Kabupaten/Kota di Provinsi Banten periode tahun 2012 - 2016, dengan Jumlah 8 Kabupaten/Kota dengan rincian, sebagai berikut :

1. Kabupaten Lebak

2. Kabupaten Pendeglang

3. Kabupaten Serang

4. Kabupaten Tangerang

5. Kota Cilegon

6. Kota Tangerang

7. Kota Serang

8. Kota Tangerang Selatan

Dengan demikian jumlah data penelitian (n) sebanyak 8 Kabupaten/Kota di Provinsi Banten untuk periode tahun 5 tahun adalah 40 data, dengan 4 varibel tinjauan yaitu Pendapatan Asli Daerah, Dana Alokasi Umum, Dana Alokasi Khusus, dan Belanja Modal, terlihat pada tabel berikut :

Pendapatan Asli Daerah, Dana Alokasi Umum, Dana Alokasi Khusus dan Belanja Modal Kabupaten/Kota di Provinsi Banten Tahun 2012 - 2016 (dalam jutaan rupiah)

\begin{tabular}{|c|c|c|c|c|c|}
\hline No. & Kabupaten/Kota & $\begin{array}{l}\text { Pendapatan } \\
\text { Asli Daerah }\end{array}$ & $\begin{array}{c}\text { Dana } \\
\text { Alokasi } \\
\text { Umum }\end{array}$ & $\begin{array}{c}\text { Dana Alokasi } \\
\text { Khusus }\end{array}$ & $\begin{array}{l}\text { Belanja } \\
\text { Modal }\end{array}$ \\
\hline \multicolumn{6}{|c|}{ Tahun 2012} \\
\hline 1 & Kabupaten Lebak & 97.190 & 804.122 & 66.461 & 298.236 \\
\hline 2 & $\begin{array}{l}\text { Kabupaten } \\
\text { Pendeglang }\end{array}$ & 63.830 & 880.970 & 104.863 & 214.509 \\
\hline 3 & Kabupaten Serang & 199.042 & 785.474 & 64.713 & 457.787 \\
\hline 4 & Kabupaten Tangerang & 503.671 & 1.016 .903 & 84.826 & 716.187 \\
\hline 5 & Kota Cilegon & 229.862 & 405.584 & 329 & 175.257 \\
\hline 6 & Kota Tangerang & 393.832 & 747.696 & 6.851 & 494.213 \\
\hline 7 & Kota Serang & 36.516 & 442.555 & 49.458 & 135.497 \\
\hline 8 & $\begin{array}{l}\text { Kota Tangerang } \\
\text { Selatan }\end{array}$ & 365.915 & 473.310 & 46.693 & 532.247 \\
\hline \multicolumn{6}{|c|}{ Tahun 2013} \\
\hline 1 & Kabupaten Lebak & 123.840 & 901.740 & 121.186 & 317.513 \\
\hline 2 & $\begin{array}{l}\text { Kabupaten } \\
\text { Pendeglang }\end{array}$ & 71.397 & 988.536 & 141.861 & 235.071 \\
\hline 3 & Kabupaten Serang & 257.054 & 868.653 & 75.494 & 422.042 \\
\hline 4 & Kabupaten Tangerang & 629.854 & 1.115 .365 & 120.034 & 867.785 \\
\hline 5 & Kota Cilegon & 208.188 & 461.400 & 5.500 & 198.921 \\
\hline 6 & Kota Tangerang & 563.108 & 829.388 & 27.706 & 968.475 \\
\hline 7 & Kota Serang & 51.694 & 513.769 & 35.556 & 121.732 \\
\hline 8 & $\begin{array}{l}\text { Kota Tangerang } \\
\text { Selatan }\end{array}$ & 485.737 & 536.177 & 885 & 612.738 \\
\hline \multicolumn{6}{|c|}{ Tahun 2014} \\
\hline 1 & Kabupaten Lebak & 236.900 & 1.000 .879 & 104.216 & 369.398 \\
\hline 2 & $\begin{array}{l}\text { Kabupaten } \\
\text { Pendeglang } \\
\end{array}$ & 110.952 & 1.077 .078 & 128.026 & 358.884 \\
\hline 3 & Kabupaten Serang & 368.633 & 950.705 & 83.750 & 526.956 \\
\hline 4 & Kabupaten Tangerang & 1.147 .560 & 1.213 .858 & 103.912 & 1.221 .057 \\
\hline 5 & Kota Cilegon & 361.741 & 40.918 & 481 & 290.787 \\
\hline 6 & Kota Tangerang & 1.084 .022 & 890.213 & 38.067 & 900.448 \\
\hline
\end{tabular}




\begin{tabular}{|c|c|c|c|c|c|}
\hline 7 & Kota Serang & 69.651 & 564.283 & 42.079 & 150.062 \\
\hline 8 & $\begin{array}{l}\text { Kota Tangerang } \\
\text { Selatan }\end{array}$ & 799.987 & 566.429 & 23.972 & 1.053 .773 \\
\hline \multicolumn{6}{|c|}{ Tahun 2015} \\
\hline 1 & Kabupaten Lebak & 243.013 & 1.029 .229 & 115.018 & 480.090 \\
\hline 2 & $\begin{array}{l}\text { Kabupaten } \\
\text { Pendeglang }\end{array}$ & 129.948 & 1.107 .070 & 122.545 & 365.119 \\
\hline 3 & Kabupaten Serang & 484.222 & 970.418 & 71.431 & 621.049 \\
\hline 4 & Kabupaten Tangerang & 1.428 .991 & 1.212 .935 & 75.609 & 1.651 .061 \\
\hline 5 & Kota Cilegon & 442.259 & 514.376 & & 404.626 \\
\hline 6 & Kota Tangerang & 1.313 .554 & 887.034 & 35.067 & 942.267 \\
\hline 7 & Kota Serang & 84.730 & 584.907 & 51.710 & 161.587 \\
\hline 8 & $\begin{array}{l}\text { Kota Tangerang } \\
\text { Selatan }\end{array}$ & 963.222 & 609.519 & 25.074 & 1.156 .530 \\
\hline \multicolumn{6}{|c|}{ Tahun 2016} \\
\hline 1 & Kabupaten Lebak & 263.120 & 1.100 .337 & 688.397 & 375.824 \\
\hline 2 & $\begin{array}{l}\text { Kabupaten } \\
\text { Pendeglang }\end{array}$ & 160.718 & 1.184 .991 & 643.252 & 509.815 \\
\hline 3 & Kabupaten Serang & 558.067 & 1.090 .140 & 398.920 & 624.491 \\
\hline 4 & Kabupaten Tangerang & 1.589 .454 & 1.196 .643 & 551.988 & 1.497 .404 \\
\hline 5 & Kota Cilegon & 539.064 & 605.983 & 209.171 & 492.780 \\
\hline 6 & Kota Tangerang & 1.458 .729 & 881.600 & 334.164 & 1.089 .340 \\
\hline 7 & Kota Serang & 107.857 & 647.986 & 220.278 & 199.541 \\
\hline 8 & $\begin{array}{l}\text { Kota Tangerang } \\
\text { Selatan }\end{array}$ & 1.196 .706 & 581.506 & 226.297 & 1.292 .810 \\
\hline
\end{tabular}

Sumber : www.djpk.kemenkeu.go.id

\section{Statistik Deskriptif}

Dari hasil pengumpulan data sekunder mengenai Pendapatan Asli Daerah, Dana Alokasi Umum, Dana Alokasi Khusus, dan Anggaran Belanja Modal pada Kabupaten/Kota di Provinsi Banten Tahun 2012-2016, maka nilai minimum, maksimum, mean, dan standar deviasi variabel penelitian adalah sebagai berikut :

\section{Statistik atas Pengolahan Data \\ Descriptive Statistics}

\begin{tabular}{|l|r|r|r|r|r|}
\hline & N & Minimum & Maximum & Mean & Std. Deviation \\
\hline PAD_X1 & 40 & 36516 & 1589454 & 485595.75 & 446514.836 \\
DAU_X2 & 40 & 40918 & 1213858 & 807016.98 & 276448.015 \\
DAK_X3 & 40 & 0 & 688397 & 131146.00 & 167911.617 \\
BM_Y & 40 & 121732 & 1651061 & 587597.72 & 398885.272 \\
Valid N (listwise) & 40 & & & & \\
\hline
\end{tabular}

Sumber: Output SPSS 16, data sekunder yang diolah

\section{Pendapatan Asli Daerah}

Melalui hasil dari tahap proses pengolahan data dengan bantuan program SPSS Statistics Version 16, jumlah populasi yang diteliti yaitu sejumlah 40. Variabel Pendapatan Asli Daerah mempunyai nilai minimalnya sebesar Rp 36.516 yang diperoleh dari Kota Serang pada tahun 2012 dan nilai maksimalnya sebesar Rp 1.589.454 yang diperoleh dari Kabupaten Tangerang pada tahun 2016. Nilai mean 485.595,75 dan nilai standar deviasi 446.514,836. 


\section{Dana Alokasi Umum}

Melalui hasil dari tahap proses pengolahan data dengan bantuan program SPSS Statistics Version 16, jumlah populasi yang diteliti yaitu sejumlah 40. Variabel Dana Alokasi Umum mempunyai nilai minimalnya sebesar Rp 40.918 yang diperoleh dari Kota Cilegon pada tahun 2014 dan nilai maksimalnya sebesar Rp 1.213.858 yang diperoleh dari Kabupaten Tangerang pada tahun 2014. Nilai mean 807.016,98 dan nilai standar deviasi 276.448,015.

\section{Dana Alokasi Khusus}

Melalui hasil dari tahap proses pengolahan data dengan bantuan program SPSS Statistics Version 16, jumlah populasi yang diteliti yaitu sejumlah 40. Variabel Dana Alokasi Khusus mempunyai nilai minimalnya sebesar Rp 0 yang diperoleh dari Kota Cilegon pada tahun 2015 dan nilai maksimalnya sebesar Rp 688.397 yang diperoleh dari Kabupaten Lebak pada tahun 2016. Nilai mean 131.146 dan nilai standar deviasi 167.911,617.

\section{Belanja Modal}

Melalui hasil dari tahap proses pengolahan data dengan bantuan program SPSS Statistics Version 16, jumlah populasi yang diteliti yaitu sejumlah 40. Variabel Belanja Modal mempunyai nilai minimalnya sebesar Rp 121.732 yang diperoleh dari Kota Serang pada tahun 2013 dan nilai maksimalnya sebesar Rp 1.651.061 yang diperoleh dari Kabupaten Tangerang pada tahun 2015. Nilai mean 587.597,72 dan nilai standar deviasi 398.885,272.

\section{Pengujian Asumsi Klasik}

\section{Uji Normalitas}

Uji normalitas bertujuan untuk menguji apakah dalam model regresi, variabel pengganggu atau residual memiliki distribusi normal. Pada penelitian ini, uji normalitas yang digunakan untuk menguji normalitas data yaitu uji one sample Kolmogorov-Smirnov. Mengenai perolehan hasil dari uji normalitas tersebut ditunjukan dengan jika nilai signifikansinya $<\alpha=0,05$ maka data normal dan jika nilai signifikansinya $>\alpha=0,05$ maka data tidak normal. Adapun uji normalitas dengan uji One sample Kolmogorov-Smirnov sebagai berikut:

\section{Hasil Uji Normalitas}

One-Sample Kolmogorov-Smirnov Test

\begin{tabular}{|ll|r|}
\hline & & \multicolumn{2}{|c|}{$\begin{array}{c}\text { Unstandardized } \\
\text { Residual }\end{array}$} \\
\hline $\mathrm{N}$ & & 40 \\
Normal Parameters ${ }^{\mathrm{a}}$ & Mean & .0000000 \\
& Std. Deviation & 128937.84493734 \\
Most Extreme & Absolute & .186 \\
Differences & Positive & .186 \\
& Negative & -.136 \\
Kolmogorov-Smirnov Z & & 1.178 \\
Asymp. Sig. (2-tailed) & & .125 \\
\hline
\end{tabular}

a. Test distribution is Normal.

Sumber: Output SPSS 16, data sekunder yang diolah 
Hasil uji normalitas ini dapat dilihat di atas, nilai Kolmogorov-Smirnov 1,178 dengan profitabilitas signifikansi 0,125 lebih dari $\alpha=0,05$, berarti data terdistribusi secara normal, dan model regresi ini memenuhi uji normalitas.

Sedangkan pada grafik normal plot terlihat titik-titik menyebar disekitar garis diaonal dan penyebarannya agak menjauh dari garis diagonal, seperti pada gambar dibawah berikut ini :

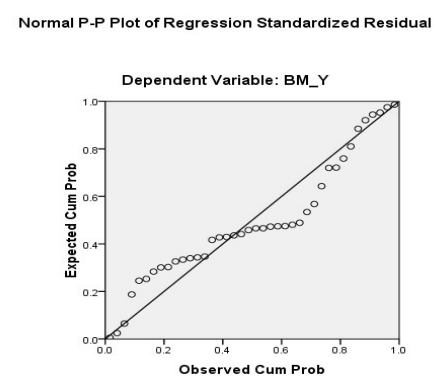

Diagram P-Plot

Sumber : Output SPSS 16, data sekunder yang diolah

\section{Uji Multikolinieritas}

Dikatakan terjadi multikolinieritas jika koefisien korelasi antar variabel bebas lebih besar 0,60, dikatakan tidak terjadi multikolinieritas jika koefisien korelasi antar variabel bebas lebih kecil atau sama dengan 0,60 $(r<0,60)$. Adapun hasil uji multikolonieritas dengan menggunakan matriks korelasi sebagai berikut:

\section{Hasil Uji Multikolonieritas}

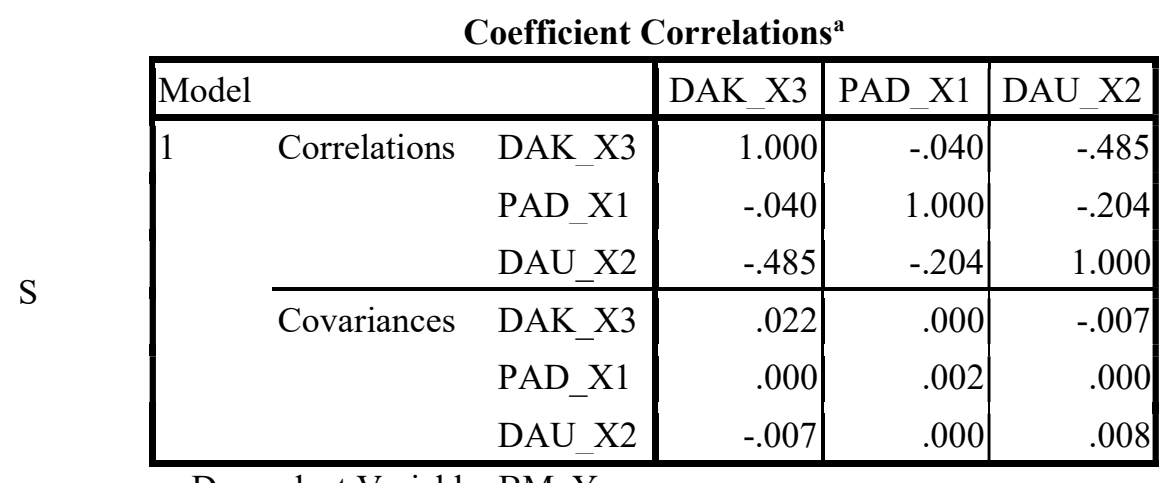

a. Dependent Variable: BM_Y

Sumber : Output SPSS 16, data sekunder yang diolah

Melihat hasil korelasi antar variabel independen tampak bahwa variabel Pendapatan Asli Daerah (PAD) memiliki korelasi cukup tinggi dengan variabel Dana Alokasi Umum (DAU) dengan tingkat korelasi sebesar -0.204, Pendapatan Asli Daerah (PAD) memiliki korelasi cukup tinggi dengan variabel Dana Alokasi Khusus (DAK) dengan tingkat korelasi sebesar -0.040, dan Dana Alokasi Umum (DAU) memiliki korelasi cukup tinggi dengan variabel Dana Alokasi Khusus (DAK) dengan tingkat korelasi sebesar -0.485. Korelasi diatas masih dibawah 0,60 atau 60\%, maka dapat dikatakan tidak terjadi multikolonieritas yang serius.

\section{Uji Heteroskedastisitas}

Uji heterokedastisitas bertujuan untuk menguji apakah dalam model regresi terjadi ketidaksamaan varian dari residual satu pengamatan ke pengamatan yang lain. Bilamana varian dari residual satu pengamatan ke pengamatan lain tetap maka disebut homokedastisitas dan bilamana berbeda disebut heterokedastisitas. 
Maka pengujian heterokedastisitas dalam penelitian ini didasari oleh grafik Scatterplot. Berdasarkan pengujian dengan SPSS diperoleh grafik Scatterplot sebagai berikut:

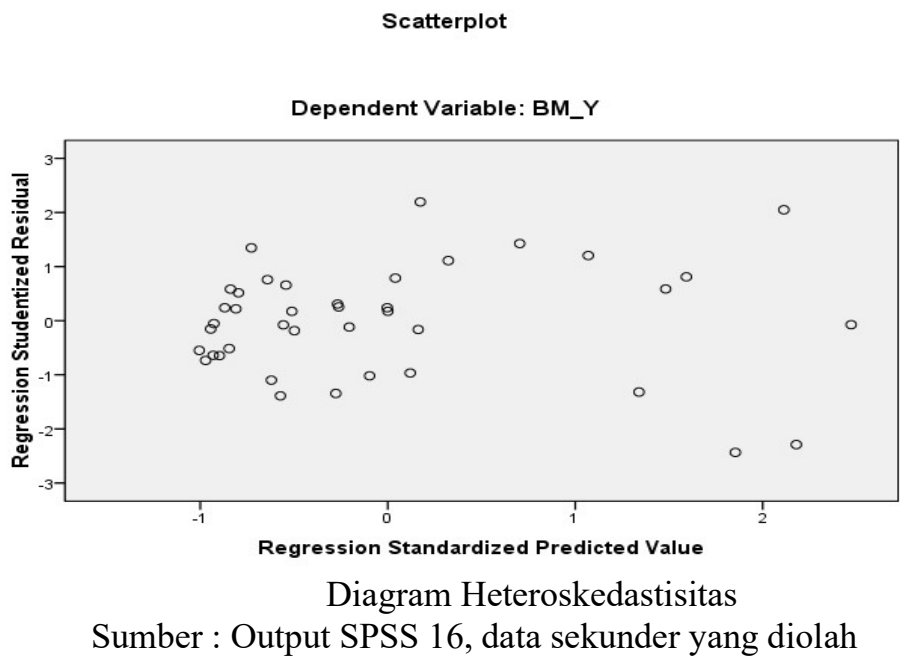

Dari gambar di atas terlihat titik - titik menyebar secara acak serta teresebar baik di atas aupun di bawah angka 0 pada sumbu Y, tidak ada pola tertentu yang teratur. Dengan demikian, dapat disimpulkan bahwa tidak terjadi heteroskedastisitas pada model regresi ini.

\section{Uji Hipotesis}

\section{Pengujian Hipotesis Secara Parsial}

Peneliti menggunakan uji t-test untuk mengetahui apakah terdapat pengaruh secara parsial antara Pendapatan Asli Daerah (X1), Dana Alokasi Umum (X2), dan Dana Alokasi Khusus (X3) terhadap Anggaran Belanja Modal (Y), signifikan apabila nilai probabilitas $<0,05$. Hasil pengolahan data pada SPSS diperoleh output Coefficients yang dapat digunakan untuk melakukan uji hipotesis secara parsial sebagai berikut:

\begin{tabular}{|c|c|c|c|c|c|}
\hline & & $\begin{array}{r}\text { Uji t-tes } \\
\text { Coefficients }^{\mathrm{a}}\end{array}$ & & & \\
\hline \multirow[b]{2}{*}{ Model } & \multicolumn{2}{|c|}{ Unstandardized Coefficients } & $\begin{array}{l}\text { Standardized } \\
\text { Coefficients }\end{array}$ & \multirow[b]{2}{*}{$\mathrm{T}$} & \multirow[b]{2}{*}{ Sig. } \\
\hline & $\mathrm{B}$ & Std. Error & Beta & & \\
\hline $1 \quad$ (Constant) & -392.061 & 68929.766 & & -.006 & .995 \\
\hline PAD_X1 & .799 & .050 & .895 & 16.046 & .000 \\
\hline DAU_X2 & .274 & .092 & .190 & 2.976 & .005 \\
\hline DAK_X3 & -.161 & .148 & -.068 & -1.086 & .285 \\
\hline
\end{tabular}

a. Dependent Variable: BM_Y

Sumber: Output SPSS 16, data sekunder yang diolah

Dari tabel diatas, Pendapatan Asli Daerah (X1), menunjukan bahwa thitung 16,046 > ttabel 2,02809 dan memiliki Sig. $0,000<0,05$ yang berarti signifikan. Signifikan disini berarti Ho1 ditolak dan Hal diterima. Artinya, variabel Pendapatan Asli Daerah (X1) secara parsial berpengaruh terhadap Anggaran Belanja Modal (Y). Dana Alokasi Umum (X2), bahwa thitung 2,976 > ttabel 2,02809 dan memiliki Sig. 0,005 $<0,05$ yang berarti signifikan. Signifikan disini berarti Ho2 ditolak dan Ha2 diterima. Artinya, variabel Dana Alokasi Umum (X2) secara parsial 
berpengaruh terhadap Anggaran Belanja Modal (Y). Selanjutnya Dana Alokasi Khusus (X3), bahwa thitung $1.086<$ ttabel 2,02809 dan memiliki Sig. 0,285 >0,05 yang berarti tidak signifikan. Tidak signifikan disini berarti Ho3 diterima dan Ha3 ditolak. Artinya, variabel Dana Alokasi Khusus (X3) secara parsial tidak berpengaruh terhadap Anggaran Belanja Modal (Y).

\section{Pengujian Hipotesis Secara Simultan}

Hasil pengolahan data dengan SPSS dapat dilihat pada tabel 4.6. Pada tabel tersebut terdapat F hitung dengan nilai probabilitas (sig) $=0,000<0,05$ dan nilai $\mathrm{F}$ hitung sebesar 102,846. Dengan menggunakan tingkat keyakinan $95 \%, \propto=5 \%$, df 1 (jumlah variabel -1$)=3$, dan df $2(\mathrm{n}-\mathrm{k}-1$ ) atau $40-3-1=36$ (n adalah jumlah data dan $\mathrm{k}$ adalah jumlah variabel independen), hasil diperoleh untuk F tabel sebesar 2,87.

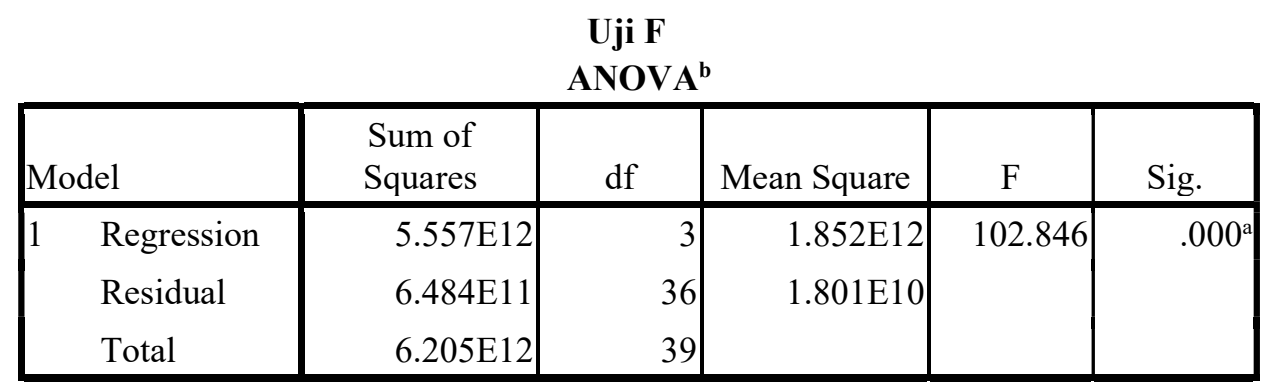

a. Predictors: (Constant), DAK_X3, PAD_X1, DAU_X2

b. Dependent Variable: BM_Y

Sumber: Output SPSS 16, data sekunder yang diolah

Karena nilai sig $=0,000<0,05$, maka ketiga variabel Pendapatan Asli Daerah (X1), Dana Alokasi Umum (X2), dan Dana Alokasi Khusus (X3) memberikan pengaruh secara signifikan terhadap Anggaran Belanja Modal (Y). Kemudian F hitung 102,846 > 2,87 F tabel, maka Ho4 ditolak dan Ha4 diterima, yang berarti ketiga variabel Pendapatan Asli Daerah (X1), Dana Alokasi Umum (X2), dan Dana Alokasi Khusus (X3) secara bersama-sama (simultan) berpengaruh terhadap Anggaran Belanja Modal (Y).

Uji Regresi Linier Berganda

Analisis Regresi Linier Berganda

Coefficients $^{\mathrm{a}}$

\begin{tabular}{|c|c|c|c|c|c|}
\hline \multirow[b]{2}{*}{ Model } & \multicolumn{2}{|c|}{ Unstandardized Coefficients } & \multirow{2}{*}{$\begin{array}{c}\text { Standardized } \\
\text { Coefficients } \\
\text { Beta }\end{array}$} & \multirow[b]{2}{*}{$\mathrm{t}$} & \multirow[b]{2}{*}{ Sig. } \\
\hline & $\mathrm{B}$ & Std. Error & & & \\
\hline $1 \quad$ (Constant) & -392.061 & 68929.766 & & -.006 & .995 \\
\hline PAD_X1 & .799 & .050 & .895 & 16.046 & .000 \\
\hline DAU_X2 & .274 & .092 & .190 & 2.976 & .005 \\
\hline DAK_X3 & -.161 & .148 & -.068 & -1.086 & .285 \\
\hline
\end{tabular}

a. Dependent Variable: BM_Y

Sumber: Output SPSS 16, data sekunder yang diolah

Dari hasil perhitungan regresi linier berganda pada tabel di atas, dapat diketahui hubungan antar variabel independen dan variabel dependen yang dapat dirumuskan dalam rumus sebagai berikut: 
Belanja Modal $=-392,061+0,799 \mathrm{PAD}+0,274 \mathrm{DAU}+(-0,161 \mathrm{DAK})$

Persamaan tersebut dapat diartikan:

1. Konstanta sebesar - 392,061 menyatakan bahwa jika tidak ada variabel independen dianggap konstan $(X 1=0, X 2=0, X 3=0)$, maka Anggaran Belanja Modal tiap daerah sebesar -392,061.

2. Koefisien Pendapatan Asli Daerah (PAD) bertambah sebesar 0,799, artinya apabila terjadi perubahan PAD sebesar 1\% akan menaikkan Anggaran Belanja Modal sebesar 0,799 atau 79,9\%.

3. Koefisien Dana Alokasi Umum (DAU) bertambah sebesar 0,274, artinya apabila terjadi perubahan DAU sebesar 1\% akan menaikkan Anggaran Belanja Modal sebesar 0,274 atau 27,4\%.

4. Koefisien Dana Alokasi Khusus (DAK) sebesar -0,161, artinya apabila terjadi perubahan DAK sebesar 1\% akan menurun Anggaran Belanja Modal sebesar 0,161 atau 16,1\%.

\section{Koefisien Determinasi}

Koefisien determinasi $\left(\mathrm{R}^{2}\right)$ pada intinya mengukur seberapa jauh kemampuan model dalam menerangkan variasi variabel dependen. Nilai koefisien determinasi adalah antara nol dan satu. Nilai $\mathrm{R}^{2}$ yang kecil berarti kemampuan variabel-variabel independen memberikan hampir semua informasi yang dibutuhkan untuk memprediksi variasi variabel dependen. Koefisien determinasi adalah kuadrat dari nilai kolerasi pada tabel Model Summary Output SPSS yang dapat dihasilkan pada berikut ini:

\section{Koefisien Determinasi} Model Summary ${ }^{b}$

\begin{tabular}{|c|r|r|r|c|}
\hline Model & $\mathrm{R}$ & $\begin{array}{r}\mathrm{R} \\
\text { Square }\end{array}$ & $\begin{array}{r}\text { Adjuste } \\
\text { d R Square }\end{array}$ & $\begin{array}{c}\text { Std. Error of } \\
\text { the Estimate }\end{array}$ \\
\hline 1 & .9 & .89 & .887 & 134202.764 \\
\hline
\end{tabular}

a. Predictors: (Constant), DAK_X3, PAD_X1, DAU_X2

b. Dependent Variable: BM_Y

Sumber: Output SPSS 16, data sekunder yang diolah

Berdasarkan tabel determinasi di atas diperoleh bahwa nilai koefisien determinasi (adjusted $\mathrm{R}^{2}$ ) sebesar 0,887 atau sebesar 88,7\%. Hal ini berarti bahwa variabel Pendapatan Asli Daerah (X1), Dana Alokasi Umum (X2), dan Dana Alokasi Khusus (X3) mampu menjelaskan variabel Anggaran Belanja Modal (Y) sebesar 88,7\%, sedangkan sisanya 11,3\%, dipengaruhi oleh faktor-faktor lain yang tidak dimasukkan dalam model regresi.

Hasil Penelitian

1. Pengaruh Pendapatan Asli Daerah (PAD) terhadap Anggaran Belanja Modal

Terdapat pengaruh signifikan Pendapatan Asli Daerah (PAD) terhadap Anggaran Belanja Modal Kabupaten/Kota di Provinsi Banten. Hasil ini menunjukan bahwa semakin tinggi Pendapatan Asli Daerah maka Anggaran Belanja Modal akan semakin meningkat, begitu pula sebaliknya apabila semakin rendah Pendapatan Asli Daerah maka Anggaran Belanja Modal akan semakin rendah. Berdasarkan hasil penelitian di atas, dapat menggambarkan bahwa semakin besar Pendapatan Asli Daerah yang diperoleh dan pemanfaatan dari Pendapatan Asli Daerah yang benar membuat besaran dana yang disalurkan pemerintah daerah untuk melakukan Anggaran Belanja Modal dapat menjadi besar.

2. Pengaruh Dana Alokasi Umum (DAU) terhadap Anggaran Belanja Modal

Terdapat pengaruh signifikan Dana Alokasi Umum (DAU) terhadap Anggaran Belanja Modal Kabupaten/Kota di Provinsi Banten", atau DAU mempunyai pengaruh positif dan signifikan terhadap Anggaran Belanja Modal. Hasil ini menunjukan bahwa semakin tinggi Dana Alokasi 
Umum maka Anggaran Belanja Modal akan semakin meningkat, begitu pula sebaliknya apabila semakin rendah Pendapatan Asli Daerah maka Anggaran Belanja Modal akan semakin rendah. Dana Alokasi Umum merupakan dana yang berasal dari APBN yang dialokasikan dengan tujuan pemerataan keuangan antar daerah untuk membiayai kebutuhan pengeluaran dalam rangka pelaksanaan desentralisasi. Hal ini berkaitan dengan perimbangan keuangan antara pusat dengan daerah. Transfer ini pengaruhnya cukup signifikan sehingga pemerintah daerah dapat menggunakannya untuk memberi pelayanan publik yang lebih baik.

3. Pengaruh Dana Alokasi Khusus (DAK) terhadap Anggaran Belanja Modal

Tidak terdapat pengaruh Dana Alokasi Khusus (DAK) terhadap Anggaran Belanja Modal Kabupaten/Kota di Provinsi Banten, terbukti yaitu Dana Alokasi Khusus mempunyai penegaruh negatif terhadap Anggaran Belanja Modal. Karena besarnya alokasi Dana Alokasi Khusus relatif kecil dibandingkan dengan dana perimbangan lainnya, khususnya jaika dibandingkan dengan DAU, sehingga peningkatan Dana Alokasi Khusus hanya mengandalkan pertumbuhan ekonomi (APBN). 


\section{KESIMPULAN}

Berdasarkan hasil penelitian dan pembahasan, maka dapat diambil kesimpulan bahwa:

1. Pendapatan Asli Daerah berpengaruh positif dan signifikan terhadap Anggaran Belanja Modal Kabupaten/Kota di Provinsi Banten Tahun 2012 - 2016. Hal ini ditunjukkan thitung 16,046 > ttabel 2,02809 dan memiliki Sig. 0,000 $<0,05$ yang berarti signifikan. Pemerintahan Daerah yang memiliki Pendapatan Asli Daerah yang tinggi maka pengeluaran untuk alokasi Anggaran Belanja Modal juga semakin tinggi.

2. Dana Alokasi Umum berpengaruh positif dan signifikan terhadap Anggaran Belanja Modal Kabupaten/Kota di Provinsi Banten Tahun 2012 - 2016. Hal ini ditunjukkan dengan thitung 2,976 $>$ ttabel 2,02809 dan memiliki Sig. 0,005 $<0,05$ yang berarti signifikan. Pemerintahan Daerah yang memiliki Dana Alokasi Umum yang tinggi maka pengeluaran untuk alokasi Anggaran Belanja Modal juga semakin tinggi.

3. Dana Alokasi Khusus berpengaruh negatif terhadap Anggaran Belanja Modal Kabupaten/Kota di Provinsi Banten Tahun 2012 - 2016. Hal ini ditunjukkan dengan thitung $1.086<$ ttabel 2,02809 dan memiliki Sig. 0,285 >0,05 yang berarti tidak signifikan. Dana Alokasi Khusus dan Anggaran Belanja Modal menunjukan hubungan yang kurang erat.

5. Pendapatan Asli Daerah (PAD), Dana Alokasi Umum (DAU), dan Dana Alokasi Khusus (DAK) berpengaruh positif dan signifikan terhadap Anggaran Belanja Modal Kabupaten/Kota di Provinsi Banten Tahun 2012 - 2016. Hal ini ditunjukkan dengan F hitung 102,846 > 2,87 F tabel.

6. Variabel Pendapatan Asli Daerah (X1), Dana Alokasi Umum (X2), dan Dana Alokasi Khusus (X3) mampu menjelaskan variabel Anggaran Belanja Modal (Y) sebesar 88,7\%, sedangkan sisanya $11,3 \%$, dipengaruhi oleh faktor-faktor lain yang tidak dimasukkan dalam model regresi. 


\section{DAFTAR PUSTAKA}

Budiarti, Pipit. 2014. Pengaruh Pendapatan Asli Daerah (PAD) Dan Dana Alokasi Umum (DAU) Terhadap Struktur Belanja Daerah. Jurnal Akuntansi, Volume XII No. 1, Universitas Brawijaya Malang.

Danang, Sunyoto. 2007. Analisis Regresi dan Korelasi Bivariat : Ringkasan dan Kasus. Yogyakarta : Amara Books.

Ghozali, Imam. 2011. Aplikasi Analisis Multivariate dengan Program IBM SPSS 19. Edisi 5. Semarang : Badan Penerbit Universitas Diponegoro.

Lembaran Negara Republik Indonesia. Peraturan Menteri Dalam Negeri Nomor 13 Tahun 2006 Tentang Pedoman Pengelolaan Keuangan Daerah.

Lembaran Negara Republik Indonesia. Peraturan Menteri Keuangan Republik Indonesia Nomor 06/pmk.07/2012 Tentang Pelaksanaan Dan Pertanggungjawaban Anggaran Tranfer ke Daerah.

Lembaran Negara Republik Indonesia. Peraturan Pemerintah Nomor 71 Tahun 2010 Tentang Standar Akuntansi Pemerintahan.

Lembaran Negara Republik Indonesia. Undang-Undang Nomor 33 Tahun 2004 Tentang Perimbangan Keuangan Antara Pemerintah Pusat Dan Pemerintah Daerah.

Manajemen Situs DJPK. "Setelah TA 2006“. $20 \quad$ Maret 2017. http://www.djpk.depkeu.go.id/?page id=316

Mardiasmo. 2002. Otonomi dan Manajemen Keuangan Daerah. Yogyakarta : Penerbit Andi Yogyakarta.

Nuarisa, Sheila Ardhian. 2013. Pengaruh PAD, DAU, DAK Terhadap Pengalokasian Anggaran Belanja Modal. Accounting Analysis Journal, 2 (3): 90 - 95, Universitas Negeri Semarang.

Nordiawan, Deddi. 2012. Akuntansi Pemerintahan. Jakarta : Salemba Empat.

Renyowijoyo, Muindro. 2010. Akuntansi Sektor Publik : Organisasi Non Laba, Jakarta : Mitra Wacana Media.

Sugiyono. 2007. Statistik Untuk Penelitian. Bandung : Penerbit Alfabeta Syafitri, Irma. 2009. Pengaruh Pertumbuhan Ekonomi,

Wandira, Arbie Gugus. 2013. Pengaruh Pendapatan Asli Daerah (PAD), Dana Alokasi Umum (DAU), Dana Alokasi Khusus (DAK), Dan Dana Bagi Hasil (DBH) Terhadap Pengalokasian Belanja Modal. Jurnal Akuntansi, Volume 2 Nomor 1, Universitas Negeri Semarang. 